\title{
Aviation's Normal Operations Safety Audit: a safety management and educational tool for health care? Results of a small-scale trial
}

This article was published in the following Dove Press journal:

Risk Management and Healthcare Policy

8 August 2017

Number of times this article has been viewed

\section{Simon A Bennett \\ Civil Safety and Security Unit, School of Business, University of Leicester, Leicester, UK}

Background: A National Health Service (NHS) contingent liability for medical error claims of over $£ 26$ billion.

Objectives: To evaluate the safety management and educational benefits of adapting aviation's Normal Operations Safety Audit (NOSA) to health care.

Methods: In vivo research, a NOSA was performed by medical students at an English NHS Trust. After receiving training from the author, the students spent 6 days gathering data under his supervision.

Results: The data revealed a threat-rich environment, where errors - some consequential - were made ( 359 threats and 86 errors were recorded over 2 weeks). The students claimed that the exercise improved their observational, investigative, communication, teamworking and other nontechnical skills.

Conclusion: NOSA is potentially an effective safety management and educational tool for health care. It is suggested that 1) the UK General Medical Council mandates that all medical students perform a NOSA in fulfillment of their degree; 2) the participating NHS Trusts be encouraged to act on students' findings; and 3) the UK Department of Health adopts NOSA as a cornerstone risk assessment and management tool.

Keywords: aviation, safety audit, health care, management benefits, educational benefits

\section{Introduction}

The Institute of Medicine ${ }^{1}$ has argued for a better understanding of the systemic causes of medical error. The Department of $\mathrm{Health}^{2}$ has argued for a wider appreciation of the value of the systems approach in preventing medical error. The National Patient Safety Agency promotes systems-thinking:

The best way of [...] reducing error rates is to target the underlying systems failures rather than take action against individual members of staff [...]. A much wider appreciation of the value of the systems approach in preventing, analyzing and learning from patient safety incidents [is required]. ${ }^{3}$

Despite these exhortations, medicine's safety praxis has been little influenced by the systems approach:

While being widely championed in patient safety, where factors related to individuals, technology and the wider organization are afforded equal consideration [...] there is $[\ldots]$ evidence that the systems approach $[\ldots]$ is still underexploited and could be taken much further. ${ }^{4}$
Correspondence: Simon A Bennett

Civil Safety and Security Unit, School of Business, University of Leicester, Leicester LEI 7RH, UK

Tel +440II6 2297577

Email sab22@le.ac.uk 
The National Health Service's (NHS's) failure to embrace the systems approach has occurred against the backdrop of a growing contingent liability for medical error:

With potential legal claims, mostly for clinical negligence, now totalling more than $£ 26$ billion, the NHS is facing unsustainable liabilities [...]. There is no sign of any improvement in reducing the incidence of harm being caused to patients $[\ldots] .5$

Against this backdrop of limited progress in the application of systems-thinking and a growing contingent liability, a proactive, systems-thinking-inspired risk management tool - the Normal Operations Safety Audit (NOSA) - was trialed at an English NHS Trust.

Organised by a university medical school, this research had three objectives:

1. to evaluate the safety benefits of conducting a NOSA in various clinical settings;

2. to assess whether fifth-year medical students could conduct a NOSA;

3. to assess the educational benefits for students of conducting an audit.

The project was developed and supervised by the paper's author (referred to as "Convenor"). The author is certificated to work on the flight-deck. He has spent $1470 \mathrm{~h}$ on the jump seat, these hours being accumulated as follows: 232 sectors (a sector being an airport-to-airport flight) on the A319; 66 sectors on the A320; 62 sectors on the A321; 82 sectors on the $\mathrm{B} 737 ; 181$ sectors on the $\mathrm{B} 757$ and 7 sectors on the $\mathrm{A} 300$. The author has flown gliders and has performed a landing in a 737-300 simulator.

Regarding the research described in this paper, ethical permission was granted by the University of Leicester, England's University Ethics Sub-Committee for Medicine and Biological Sciences. The agreed project title was "Exploring the value of holistic observations of clinical practice: developing a student observational learning tool". The observers were full-time medical students who volunteered. The ethics sub-committee did not require the study to obtain observers' or observees' consent. This was an integral part of the observers' medical degree.

\section{Systems-thinking - its meaning and application in aviation}

Systems-thinking draws on ethnography, participant observation, action research, oral history and mass observation. To paraphrase Waterson and Catchpole, ${ }^{4}$ systems-thinking is not so much about applying the "right" type of knowledge to a problem, but about applying the right approach. Systems- thinking is a frame of reference with a simple premise - that human error can be induced. For example, a badly designed display may cause a pilot to misread an instrument. ${ }^{6}$

\section{Systems-thinking in aviation}

Aviation has pioneered the systems-thinking approach to risk management and accident investigation. Watershed moments include Moshansky's $1992^{7}$ analysis of the 1989 Dryden accident and Haddon-Cave's $2009^{8}$ analysis of the 2006 Nimrod loss. Complex systems - prone to dynamic events such as emergence and practical drift and subject to social, economic and political pressures - are difficult to manage. ${ }^{9-14}$ Lagadec $^{15}$ and Perrow ${ }^{16}$ associate complexity with vulnerability. Understanding how in reality systems work is the sine qua non of successful system management.

The 1972 Florida Tri-Star disaster ${ }^{17}$ (101 dead) and the 1977 Tenerife disaster ${ }^{18}$ (583 dead) convinced the industry that it needed:

1. a better understanding of routine flight operations and

2. improved teamworking, both on and around aircraft.

Human factors tools were developed. First, crew resource management improved teamwork and resource utilization. ${ }^{19,20}$ Second, NOSA documented the reality of flight operations.

\section{NOSA}

Recognizing the mutability of the system as designed, NOSA documents the system as found. Systems-thinking tools, such as NOSA, assume system behavior to be an emergent property of complex, hard-to-discern interactions between human and nonhuman components (e.g., personnel, equipment, resourcing, rules, regulations, personal ambition, corporate aspirations and the law). Systems-thinking challenges the false certainties of reductionism. ${ }^{14}$

Executed by trained observers familiar with flight operations, a NOSA reveals the lived reality - the verité of flight-deck labor. Observers' freedom to roam and probe reflects NOSA's grounding in actor-network theory, specifically Latour' $\mathrm{s}^{21}$ exhortation that researchers must "follow the actors".

A NOSA is sensitive to phenomena such as practical drift and emergence, where "simple entities, because of their interaction $[\ldots]$ can produce far more complex behaviors as a collective $[\ldots] " .{ }^{22}$ A NOSA describes:

1. the threat environment (e.g., substandard air traffic control);

2. the number and type of errors made by flight crew (e.g., intentional noncompliance with a rule); 
3. coping mechanisms:

$[R]$ outine threats to the safety $[\ldots]$ of the system are constantly being managed by the system before they lead to serious outcomes $[\ldots]$ this information is often not captured [...] by the organization. [NOSA] provides a means by which this can be achieved, ${ }^{23}$

4. good practice (e.g., safety innovations introduced by personnel). ${ }^{24}$

NOSA meets Hollnagel's ${ }^{25}$ Safety-II standard. Specifically:

1. safety management should be proactive;

2. safety initiatives should be tailored through topographic research;

3. because of their local knowledge, workers should be at the center of risk management processes.

The NOSA methodology is promoted by the International Civil Aviation Organization.

\section{Methodology}

An example of action research, the project tested claims that a NOSA can - by producing a topographic account - help managers understand the lived reality of a labor process. A literature search conducted in early 2016 by the medical school found no references to NOSA in the medical safety literature.

\section{Potential impacts - pedagogic}

With reference to theories of immersive/experiential learning $^{26}$ and action learning, ${ }^{27,28}$ the project offered students the opportunity to:

1. conduct in vivo research into a complex, politically charged and difficult to solve problem (patient harm);

2. be within a bespoke problem-solving team;

3. use a research instrument that demands of the user solid nontechnical skills;

4. with the possibility that findings would inform policy and action.

Potentially the project would improve students' teamworking, observational, communication and problem-solving skills.

\section{Potential impacts - organizational}

Denscombe ${ }^{29}$ observed, "Early on, action research was [...] seen as research specifically geared to changing matters [...] this has remained a core feature $[\ldots] "$. Lewin ${ }^{30}$ characterized action research as a "spiral of steps [...] composed of a circle of planning, action and fact-finding about the result of the action".
Drawing on Lewin's ${ }^{30}$ and Denscombe's ${ }^{29}$ formulation, the Convenor intended the data to provoke change within the research setting (the Trust). To this end, he:

1. organized a feedback session for participating medical practitioners and academics;

2. wrote a journal paper;

3. sought funding for a larger project.

\section{Research instrument}

Unlike an aircraft flight-deck, a medical facility (e.g., an accident and emergency department) is a permeable workspace open to actors with varied roles (e.g., doctors, nurses, ambulance crew, porters, cleaners, police officers). Consequently, the standard University of Texas Human Factors Research Project NOSA Threat and Error Management Worksheet $^{31}$ was simplified to create the more functional Threat and Error Assessment and Management Worksheet (TEAM-W; Figure 1).

The TEAM-W coding system (Table 1) was developed by a clinician with a working knowledge of NOSA. It is reproduced in the "Quantitative analysis" section.

\section{Reflections on the methodology}

Reflection $^{32}$ revealed potential pitfalls:

1. The data could be skewed by the Hawthorne effect: persons subject to observation may modify their behavior. ${ }^{33}$

2. The data could be skewed by experimenter bias: observees' identification with the observer may cause them to modify their behavior.

3. The data could be skewed by observer bias: observers' preconceptions may influence the choice of scenario and interpretation of same.

4. The data could be skewed by TEAM-W's coding structure: to a degree, coding systems focus researchers' attention.

5. Observer cognitive overload could cause data to be misinterpreted or lost: information overload and prioritization errors can result in observer task saturation, reducing situation awareness. ${ }^{34}$ Medical settings can appear chaotic.

6. Knowledge deficit could reduce accuracy: student-observers might lack the knowledge and experience required to make accurate observations.

7. TEAM-W could be dismissed as derivative: "[R] esearch is never conducted without reference to other studies". ${ }^{35}$

\section{Research team}

The researchers were university medical school fifth-year students due to progress to foundation training in 2017. In the United Kingdom, medical graduates who elect to work in 


\begin{tabular}{|c|c|c|c|c|c|}
\hline \multicolumn{6}{|l|}{ Sheet Number } \\
\hline Event & $\begin{array}{c}\text { Threat } \\
X\end{array}$ & $\begin{array}{c}\text { Error } \\
X\end{array}$ & $\begin{array}{l}\text { How event was managed and } \\
\text { outcome(s) }\end{array}$ & Lessons learned by observer & $\begin{array}{l}\text { Event } \\
\text { code }\end{array}$ \\
\hline & & & & & \\
\hline & & & & & \\
\hline & & & & & \\
\hline & & & & & \\
\hline & & & & & \\
\hline & & & & & \\
\hline & & & & & \\
\hline & & & & & \\
\hline & & & & & \\
\hline & & & & & \\
\hline & & & & & \\
\hline & & & & & \\
\hline & & & & & \\
\hline & & & & & \\
\hline & & & & & \\
\hline & & & & & \\
\hline & & & & & \\
\hline & & & & & \\
\hline & & & & & \\
\hline & & & & & \\
\hline
\end{tabular}

Figure I Blank Threat and Error Assessment and Management Worksheet.

the National Health Service spend up to nine years as a Junior Doctor. Two years are spent as a Junior Doctor foundation trainee, then either three years as a GP trainee, or seven years as a Hospital Speciality trainee. ${ }^{37}$

Students volunteered to join the team in fulfillment of one of the student selected components (SSCs) of their degree (The General Medical Council mandates that SSCs must constitute a minimum of $10 \%$ of course time. SSCs allow students to demonstrate mandatory competencies.). The project commenced with a day's introduction to TEAM-W. The training mixed a video presentation - the award-winning educational video "Recognizing risk and improving patient safety - Mildred's Story" ${ }^{38}$ re-presented through a NOSA lens - with PowerPoint presentations and a question-andanswer session.

The 11 volunteers ( 7 females, 4 males) were divided into five mixed-gender groups (four groups of 2 students and one group of 3). They were given a timetable of appointments with clinicians and told that they would return for an interim wash-up (debrief) at the end of Week 1 and a final wash-up at the end of Week 2 . They were told that:

1. each group would make a case study-based PowerPoint presentation in the final wash-up;
2. each student would complete a Competence Log Book (to be signed off by the Convenor), as shown in Figure S1 (only the first two pages are shown);

3. each student would complete their own TEAM-Ws, to be given to the Convenor at the final wash-up in either electronic or hard-copy form.

During his visits with the various teams, the Convenor made notes, some of which he later transcribed onto TEAM-Ws.

\section{Fieldwork}

Ethical permission was granted by the NHS about a month before the project commenced. Although the NHS permit did not require that participants' informed consent be secured, on request, observers discussed the purpose of their observations/questions with the observees/interviewees. The five groups rotated through a number of NHS clinical settings over a period of 2 weeks during summer. Settings included a mental health facility, a fracture clinic (acute), a urology ward and general and vascular surgery theaters. The Student Roster is reproduced in Table S1.

At liberty to talk to anyone (e.g., staff, patients, relatives) and observe any intervention or procedure, the students were able to describe: 
Table I Threat and error codes

\begin{tabular}{|c|c|}
\hline \multicolumn{2}{|l|}{ Threats (Code 100-499) } \\
\hline Code & $\begin{array}{l}\text { Scored } \\
\text { n times }\end{array}$ \\
\hline 100 Human in origin & 5 \\
\hline I0I Infection, introduced by: & 2 \\
\hline I0II Visitors & 0 \\
\hline 1012 Staff & $19 *$ \\
\hline 1013 Patients & $\mathrm{I}$ \\
\hline 102 Exhausted staff & $14 *$ \\
\hline 103 Temporary staff & 0 \\
\hline 104 Insufficient staff & $32 *$ \\
\hline 105 Insufficient range of skills among duty staff & $12 *$ \\
\hline $\begin{array}{l}106 \text { Lack of leadership - junior staff making high-level } \\
\text { decisions }\end{array}$ & 4 \\
\hline I07 Mandatory training naïve & 1 \\
\hline $\begin{array}{l}108 \text { Health and safety issue - staff, e.g., alcohol, blood- } \\
\text { borne virus, mental health }\end{array}$ & 3 \\
\hline 109 Health and safety issue - patients & 4 \\
\hline I09I Physical health & 4 \\
\hline 1092 Mental health & 6 \\
\hline 1093 Violence & 2 \\
\hline II0 Inadequate patient notes available & $31 *$ \\
\hline III Wrong patient labels in notes & 0 \\
\hline II2 Wrong investigation results filed & 0 \\
\hline I I 3 Similar patient names in a clinical arena & 2 \\
\hline $\begin{array}{l}\text { II } 4 \text { Copying and pasting from one software program to } \\
\text { another }\end{array}$ & 2 \\
\hline II5 Not logging out in clinical area & 1 \\
\hline II6 Mislabeling specimens & 2 \\
\hline II7 Mixing biopsies/smears/aspirates & 0 \\
\hline II8 Laterality & 0 \\
\hline I19 Leaving swabs in situ & 0 \\
\hline I20 Privacy and dignity & 6 \\
\hline $\begin{array}{l}\text { 1201 Staff-related, e.g., discussing patient in corridor, } \\
\text { leaving patient lying in urine and so on }\end{array}$ & $24 *$ \\
\hline I202 Institution-related, e.g., no private room & $20 *$ \\
\hline I2I Abnormal result not acted upon & 0 \\
\hline I2II Not escalated & 0 \\
\hline $\begin{array}{l}\text { I212 Escalated, but did not reach frontline team in time, } \\
\text { e.g., message not passed on }\end{array}$ & 0 \\
\hline I22 Risk of pressure sores & 0 \\
\hline I22I Lying on trolleys awaiting a bed & $\mathrm{I}$ \\
\hline I23 Risk of deep-vein thrombosis/pulmonary embolism & 0 \\
\hline I24 Too many patients on theater list or clinic & 6 \\
\hline I25 Smoking on site & 0 \\
\hline I26 Slipping & 2 \\
\hline I27 Manual handling & 3 \\
\hline I28 Cultural issues & 0 \\
\hline I28I Insensitivity to cultural norms & 0 \\
\hline I282 Imperfect knowledge of spoken tongue & $14 *$ \\
\hline $\begin{array}{l}129 \text { Information blindness (useful knowledge } \\
\text { overlooked) }\end{array}$ & 2 \\
\hline I29I Willful & 0 \\
\hline I292 Accidental & $\mathrm{I}$ \\
\hline I30 Team dynamics & $13 *$ \\
\hline Total & 239 \\
\hline
\end{tabular}

(Continued)
Table I (Continued)

\begin{tabular}{|l|l|}
\hline Threats & \\
\hline Code & $20^{*}$ \\
\hline 200 Technological in origin & 6 \\
\hline 20I Slow computers & 8 \\
\hline 202 Software misadventure & $\mathrm{I}$ \\
\hline 203 Lack of Wi-Fi & 4 \\
\hline 204 Electronic prescribing pitfalls & 2 \\
\hline $\begin{array}{l}\text { 205 Dual electronic and hard-copy prescribing on the } \\
\text { same patient }\end{array}$ & 3 \\
\hline $\begin{array}{l}206 \text { Awaiting import of digital radiology images from } \\
\text { elsewhere }\end{array}$ & $13^{*}$ \\
\hline 207 Confidentiality & 57 \\
\hline Total & \\
\hline
\end{tabular}

\begin{tabular}{|l|l|}
\hline Threats & \\
\hline Code & $\mathrm{I}$ \\
\hline 300 Building & $40^{*}$ \\
\hline 30 I Layout design & $15^{*}$ \\
\hline 302 Air conditioning & 2 \\
\hline 303 Cleanliness & 5 \\
\hline 304 Seating and posture in offices & 63 \\
\hline Total & \\
\hline
\end{tabular}

\begin{tabular}{|c|c|}
\hline \multicolumn{2}{|l|}{ Errors (Code 500-1300) } \\
\hline Code & \\
\hline 500 Prescribing & 6 \\
\hline 50I Drug due to handwriting & 0 \\
\hline 502 Drug due to drug interaction & 0 \\
\hline $\begin{array}{l}503 \text { Drug due to comorbidity, for example, renal } \\
\text { impairment, liver failure, age }\end{array}$ & 0 \\
\hline 504 Controlled drug error & 0 \\
\hline 505 Allergy & 4 \\
\hline 506 Dose & 2 \\
\hline 507 Frequency & 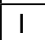 \\
\hline 508 Units & 0 \\
\hline 509 Duplicate digital and hard-copy prescribing & $\mathrm{I}$ \\
\hline 510 Blood transfusion & 0 \\
\hline 5II Radiotherapy & 0 \\
\hline $\begin{array}{l}512 \text { Inadequate or absent thromboprophylaxis leading to } \\
\text { DVT or PE }\end{array}$ & 0 \\
\hline $\begin{array}{l}513 \text { Antibiotic prophylaxis not prescribed prior to } \\
\text { procedure, leading to sepsis }\end{array}$ & 0 \\
\hline $\begin{array}{l}5 \text { I4 Failure to bridge/stop anticoagulant appropriately } \\
\text { prior to procedure, leading to bleeding }\end{array}$ & 0 \\
\hline 515 Stolen prescription pad & $\mathrm{I}$ \\
\hline Total & 15 \\
\hline
\end{tabular}

\begin{tabular}{|l|l|}
\hline Errors & \\
\hline Code & \\
\hline 600 Ordering investigations & 2 \\
\hline 601 Wrong patient & 0 \\
\hline 601 I Radiology & 0 \\
\hline 6012 Non-radiology & 0 \\
\hline 602 Wrong investigation & 2 \\
\hline Total & 4 \\
\hline
\end{tabular}


Table I (Continued)

\begin{tabular}{|l|l|}
\hline Errors \\
\hline Code & \\
\hline 700 Wrong interpretation of investigation & $\mathrm{I}$ \\
\hline 70 I Radiology, for example, missed fracture, missed tumor & 2 \\
\hline 702 Blood result & $\mathrm{I}$ \\
\hline Total & 4 \\
\hline
\end{tabular}

\begin{tabular}{|l|l|}
\hline Errors & \\
\hline Code & 7 \\
\hline $\begin{array}{l}800 \text { Appropriate investigation not performed (e.g., missed } \\
\text { fracture) }\end{array}$ & 7 \\
\hline Total & 7 \\
\hline
\end{tabular}

\begin{tabular}{|l|l|}
\hline Errors \\
\hline Code & \\
\hline $\begin{array}{l}\text { 900 Patient given wrong information (e.g., given cancer } \\
\text { diagnosis in error, leading to psychological distress, or } \\
\text { cancer sufferer told s/he is cancer-free) }\end{array}$ & 6 \\
\hline Total & 6 \\
\hline
\end{tabular}

\begin{tabular}{|l|l|}
\hline Errors & \\
\hline Code & $16^{*}$ \\
\hline I000 Equipment & 0 \\
\hline I00I Energy & $\mathrm{I}$ \\
\hline I00II Fire & 0 \\
\hline I00I2 Skin burn & 2 \\
\hline I00I3 Incorrect setting & 0 \\
\hline I00I4 Incorrect result & 0 \\
\hline I00I5 Organ injury & 0 \\
\hline I002 Anesthetic & 0 \\
\hline I003 Radiotherapy & 1 \\
\hline I004 Wrong prosthesis & 3 \\
\hline I005 Others, for example, catheter issue due to "bad batch" & 23 \\
\hline Total & \\
\hline
\end{tabular}

\begin{tabular}{|l|l|}
\hline Errors & \\
\hline Code & 0 \\
\hline II00 Mental capacity & 0 \\
\hline $\begin{array}{l}\text { II0I Failure to properly determine, leading to } \\
\text { inappropriate decision }\end{array}$ & 0 \\
\hline Total & \\
\hline
\end{tabular}

\begin{tabular}{|l|l|}
\hline Errors & \\
\hline Code & 2 \\
\hline I200 Intervention & 5 \\
\hline I20I Never-event occurs & 7 \\
\hline Total & \\
\hline
\end{tabular}

\begin{tabular}{|l|l|}
\hline Errors & \\
\hline Code & 9 \\
\hline I 300 Failing to follow prescribed procedures & $\mathrm{II}$ \\
\hline I 30 I Guidelines not followed & 0 \\
\hline I 302 Unaware of skill-set & 20 \\
\hline Total &
\end{tabular}

Note: *The Convenor judged that threat and error subcodes scored 10 or more times merited case studies.
1. subjects' actions and

2. systemic influences on behavior.

To facilitate completion of TEAM-Ws, the students were given clipboards. Appropriate ID was displayed. The days could be long and busy, with few breaks. The Convenor rotated between medical settings offering support and making his own TEAM-W notes (although not incorporated into the final data set, one observation is reproduced in Table S2 and Figure S2). There were few issues. Most staff members were receptive (despite occasionally not having been told about research). The major difficulty was locating staff and students in sprawling facilities. A representative sample of threats and errors recorded ten or more times by the students is produced in Table 2. The narratives are the students' own words.

\section{Presentations and sign-off}

On the final day of the SSC, each group made a presentation. Although invitations were sent to clinicians involved in the research, none attended. The Convenor judged the presentations to be of exceptional quality. The case studies revealed numerous issues. Students reflected on NOSA's suitability to health care. Students' reflections are listed in Box S1. The Convenor judged that all students had passed the SSC. Competence Log Books were signed-off.

\section{Student and convenor insights into the methodology}

These are as described in Box S1. Generally, the students encountered few difficulties, although the staff could occasionally be suspicious of the study. Students attributed the majority of adverse reactions to staff not being told in advance. Without exception, students claimed that the study had improved their awareness of patient safety issues. They also claimed it had improved their situation awareness, observation and communication skills and self-confidence.

Although students considered the coding system a good first attempt, all stated that it required further development. Use of a paper-based recording system (TEAM-W) made record-keeping and data analysis laborious, time-consuming and demanding. All felt that consideration should be given to developing an electronic TEAM-W for a modern digital platform, such as an iPad. In the opinion of the Convenor, this would significantly reduce the time required to mine the data for trends and patterns.

Ideally, group assessments of common settings would have been cross-checked for consistency. A number of factors made cross-checking difficult, most notably, the fact that the Convenor's budget did not include monies for the develop- 
Table 2 Qualitative analysis (case studies)

(A) Threat: 1012 infection, introduced by: staff

\begin{tabular}{|c|c|c|c|c|c|}
\hline Event & $\begin{array}{c}\text { Threat } \\
\mathbf{X}\end{array}$ & $\begin{array}{l}\text { Error } \\
\mathbf{X}\end{array}$ & $\begin{array}{l}\text { How the event was } \\
\text { managed and the } \\
\text { outcome(s) (M\&O) }\end{array}$ & $\begin{array}{l}\text { Lessons learned by the } \\
\text { observer (LL) }\end{array}$ & $\begin{array}{l}\text { Event } \\
\text { code } \\
\text { (EC) }\end{array}$ \\
\hline $\begin{array}{l}\text { The Dr did not wash hands before } \\
\text { going to see and examine the } \\
\text { patient (occurred eight times) }\end{array}$ & $x$ & & $\begin{array}{l}\text { The Dr washed hands after each } \\
\text { patient, but not before }\end{array}$ & $\begin{array}{l}\text { It is not sufficient to wash hands } \\
\text { only after seeing a patient. } \\
\text { Hands must be washed again } \\
\text { before seeing the next patient }\end{array}$ & 1012 \\
\hline $\begin{array}{l}\text { A Charge Nurse entered the } \\
\text { patient side-room without the } \\
\text { required PPE. There was a notice } \\
\text { on the door which says to use } \\
\text { aprons and gloves before entering }\end{array}$ & $x$ & $x$ & & $\begin{array}{l}\text { Patients are inside the room } \\
\text { due to infectious disease. The } \\
\text { Charge Nurse risks contracting } \\
\text { the infection himself by entering } \\
\text { without PPE, and also passing } \\
\text { the infection to other patients }\end{array}$ & 1012 \\
\hline $\begin{array}{l}\text { Failure of medical staff to change } \\
\text { PPE (apron and gloves) when } \\
\text { moving between patients in an } \\
\text { isolation bay }\end{array}$ & $x$ & $x$ & $\begin{array}{l}\text { A nurse pointed out that they } \\
\text { should be changing their PPE in } \\
\text { between each patient, and after } \\
\text { that, they did }\end{array}$ & $\begin{array}{l}\text { Staff may be aware of the } \\
\text { guidelines, but may choose } \\
\text { to follow them only when } \\
\text { reminded }\end{array}$ & 1012 \\
\hline $\begin{array}{l}\text { Doctor did not wash hands before } \\
\text { or after examining patients. Wore } \\
\text { gloves } \\
\text { Doctor washed hands once during } \\
\text { a clinic where he saw } 10 \text { patients } \\
\text { On one occasion, the consultant } \\
\text { entered and examined a patient. He } \\
\text { neither wore gloves nor washed } \\
\text { his hands. He washed his hands } \\
\text { afterwards }\end{array}$ & & $x$ & $\begin{array}{l}\text { The error was not } \\
\text { acknowledged }\end{array}$ & $\begin{array}{l}\text { Possibly, doctors believe that } \\
\text { if they use gloves, they do not } \\
\text { need to wash } \\
\text { By not washing, the consultants } \\
\text { may help normalize such } \\
\text { behavior }\end{array}$ & 1012 \\
\hline
\end{tabular}

(B) Threat: 102 exhausted staff

\begin{tabular}{|c|c|c|c|c|c|}
\hline Event & Threat & Error & M\&O & LL & EC \\
\hline $\begin{array}{l}\text { [Fracture clinic] Overworked medical staff } \\
\text { and overbooked clinic. Dr should have I5 } \\
\text { patients instead of } 20 \text {. Other Dr should have } \\
20 \text { patients instead of } 25 \text {. Nurse should have } 8 \\
\text { patients instead of } 16\end{array}$ & $\mathrm{X}$ & & $\begin{array}{l}\text { All patients were seen, but higher } \\
\text { potential to miss information, to } \\
\text { make incorrect decisions, causing } \\
\text { patient harm }\end{array}$ & $\begin{array}{l}\text { Not enough staff or resources } \\
\text { for the demands placed on the } \\
\text { department [by 2016, NHS } \\
\text { finances were precarious }{ }^{39} \text { ] }\end{array}$ & 102 \\
\hline $\begin{array}{l}\text { [Operating theater] Staff member overcome } \\
\text { by heat. Felt faint. Had to step away from the } \\
\text { operating table. Very hot. Had not had time } \\
\text { for lunch }\end{array}$ & $x$ & & Unscrubbed. Sat. Drank water & Aircon and heat problematic & 102 \\
\hline $\begin{array}{l}\text { [Operating theater] Surgeon has been on } \\
\text { feet for } 2.5 \mathrm{~h} \text {. No rest. Complains of feeling } \\
\text { uncomfortable. Shortly after he nicks artery }\end{array}$ & $\mathrm{x}$ & & Artery clamped and sutured & $\begin{array}{l}\text { No chairs available for surgeons } \\
\text { Provision for longer surgery } \\
\text { (breaks, chairs) not made }\end{array}$ & 102 \\
\hline
\end{tabular}

(C) Threat: 104 Insufficient staff

\begin{tabular}{|l|c|c|c|l|l|}
\hline Event & Threat & Error & M\&O & LL & EC \\
\hline $\begin{array}{l}\text { One HCA monitoring a four-bed bay plus three side- } \\
\text { rooms. Two patients just back from angio suite and } \\
\text { theater require 15 min observations }\end{array}$ & $X$ & & & $\begin{array}{l}\text { Competing priorities for understaffed bay } \\
\text { Observation times not achieved because of } \\
\text { competing priorities }\end{array}$ & I04 \\
\hline $\begin{array}{l}\text { HCA monitoring post-op patient unaware of what he is } \\
\text { meant to be doing. He says his English is not great, so } \\
\text { he was finding it difficult. Another member of staff kept } \\
\text { having to tell him what to write }\end{array}$ & $X$ & & $\begin{array}{l}\text { Inadequate supervision } \\
\text { Other members of staff having to support HCA } \\
\text { Lack of staff meant there was little support for the } \\
\text { new staff member }\end{array}$ & $\begin{array}{l}\text { I04 } \\
\text { and } \\
\text { I05 }\end{array}$ \\
\hline
\end{tabular}


Table 2 (Continued)

(D) Threat: 105 Insufficient range of skills among duty staff

\begin{tabular}{|c|c|c|c|c|c|}
\hline Event & Threat & Error & M\&O & LL & EC \\
\hline $\begin{array}{l}\text { [Flexible cystoscopy list, Urology] } \\
\text { Patient with an artificial urethral } \\
\text { sphincter does not know how to } \\
\text { deactivate it (which must be done } \\
\text { before the procedure) }\end{array}$ & $x$ & & $\begin{array}{l}\text { Several unsuccessful attempts were made } \\
\text { to deactivate it. The balloon would not } \\
\text { stay empty. The scope would not pass } \\
\text { The Dr called the consultant and asked the } \\
\text { patient to return to the waiting room. He } \\
\text { wanted the consultant to have a go }\end{array}$ & & 105 \\
\hline $\begin{array}{l}\text { A new device was being used in } \\
\text { theater to move patients from a } \\
\text { supine to a prone position. Some } \\
\text { staff had little experience with } \\
\text { the equipment }\end{array}$ & $x$ & & $\begin{array}{l}\text { One member of staff familiar with the } \\
\text { device was able to instruct others }\end{array}$ & $\begin{array}{l}\text { Staff are not always formally trained when } \\
\text { a new device is introduced } \\
\text { The new device was meant to reduce } \\
\text { the risk to staff of manual-handling } \\
\text { injuries, but [the manner of the device's } \\
\text { introduction] seemed to increase the risk } \\
\text { of injury to the patient }\end{array}$ & 105 \\
\hline
\end{tabular}

(E) Threat: I 10 Inadequate patient notes available

\begin{tabular}{|c|c|c|c|c|c|}
\hline Event & Threat & Error & M\&O & LL & EC \\
\hline $\begin{array}{l}\text { Information on a board in the } \\
\text { Staff Office relating to patients } \\
\text { was out of date }\end{array}$ & $x$ & & $\begin{array}{l}\text { By the end of the shift, a member of staff } \\
\text { had been identified as being responsible } \\
\text { for updating the board }\end{array}$ & $\begin{array}{l}\text { Information on patient review dates is } \\
\text { not always kept up to date } \\
\text { Once the problem was identified, } \\
\text { action was quickly taken }\end{array}$ & 110 \\
\hline $\begin{array}{l}\text { [Vascular clinic] Assuming } \\
\text { the hospital would have a } \\
\text { record of their medications, a } \\
\text { patient brought neither their } \\
\text { medications nor a list of their } \\
\text { medications }\end{array}$ & $X$ & & $\begin{array}{l}\text { The GP's letter (seen by the Dr) did } \\
\text { not list the medications the patient was } \\
\text { describing. The patient did not know } \\
\text { the names of the medications, but knew } \\
\text { vaguely how they worked. The patient } \\
\text { was given a prescription and asked to } \\
\text { check the names of the medications in the } \\
\text { prescription }\end{array}$ & $\begin{array}{l}\text { Overreliance on hospital notes } \\
\text { No coordination between the GP } \\
\text { and the hospital, that is, no shared } \\
\text { program or information } \\
\text { No request to patient asking them to } \\
\text { bring medications to clinic }\end{array}$ & 110 \\
\hline
\end{tabular}

(F) Threat: I20I Privacy and dignity: staff-related, e.g., discussing patient in the corridor, leaving patient lying in urine and so on

\begin{tabular}{|c|c|c|c|c|c|}
\hline Event & Threat & Error & M\&O & LL & EC \\
\hline $\begin{array}{l}\text { Consultant talked loudly about patient in the } \\
\text { Ward Reception Area }\end{array}$ & & $x$ & $\begin{array}{l}\text { Consultant encountered colleague } \\
\text { involved in the care of a patient who } \\
\text { was due in theater. The consultant } \\
\text { loudly proclaimed to staff present in } \\
\text { the Ward Reception Area: "[patient's } \\
\text { name deleted] scrotum is all falling } \\
\text { apart" }\end{array}$ & $\begin{array}{l}\text { There is insufficient respect for } \\
\text { privacy when discussing patients } \\
\text { with the staff } \\
\text { Information about patients is } \\
\text { not always transmitted to other } \\
\text { members of staff in appropriate } \\
\text { settings }\end{array}$ & 1201 \\
\hline $\begin{array}{l}\text { [Operating theater] Patient had been covered } \\
\text { for dignity. Surgeon uncovered patient before } \\
\text { scrub. Unnecessary }\end{array}$ & & $\mathrm{x}$ & HCA re-covered patient & $\begin{array}{l}\text { Patient only exposed when time } \\
\text { comes to drape }\end{array}$ & 1201 \\
\hline $\begin{array}{l}\text { Consultation between doctor and patient } \\
\text { occurred with the door wide open } \\
\text { This occurred for every consultation } \\
\text { observed, except one. The only time the } \\
\text { door was closed was when the doctor } \\
\text { noticed he was being observed }\end{array}$ & & $\mathrm{x}$ & $\begin{array}{l}\text { The entire consultation was done } \\
\text { with the door open }\end{array}$ & $\begin{array}{l}\text { The room had not been designed for } \\
\text { clinical consultations. It had no windows } \\
\text { and no aircon. It was a warm day. } \\
\text { Opening the door was the only way to } \\
\text { keep the room cool and comfortable } \\
\text { for both doctor and patient }\end{array}$ & 1201 \\
\hline $\begin{array}{l}\text { Consultant staff heard calling junior doctors } \\
\text { "communist". [In 2016, the government } \\
\text { imposed a new contract on junior doctors. } \\
\text { Strikes followed. NHS England postponed nearly } \\
13,000 \text { routine operations, cancelled study leave } \\
\left.\text { and holidays and redeployed consultants }{ }^{36}\right]\end{array}$ & & $x$ & Not challenged & $\begin{array}{l}\text { All work environments are } \\
\text { professional environments }\end{array}$ & 1201 \\
\hline
\end{tabular}

(Continued) 
Table 2 (Continued)

(G) Threat: I 202 Privacy and dignity: institution-related, for example, no private room

\begin{tabular}{|l|c|c|l|l|l|}
\hline Event & Threat & Error & M\&O & LL & EC \\
\hline $\begin{array}{l}\text { Curtains not closed during ward } \\
\text { round. This happened with the } \\
\text { majority of the patients }\end{array}$ & X & $\begin{array}{l}\text { Ward round continued - curtains not } \\
\text { drawn }\end{array}$ & $\begin{array}{l}\text { Poor compliance by all members of the } \\
\text { team regarding confidentiality }\end{array}$ & I202 \\
\hline $\begin{array}{l}\text { [Morning vascular ward round] } \\
\text { Patient dignity: examined femoral } \\
\text { pulses and groin in front of } \\
\text { at least nine people with the } \\
\text { curtains open }\end{array}$ & $X$ & $\begin{array}{l}\text { Examination continued. Patient } \\
\text { appeared mildly embarrassed. This } \\
\text { can undermine trust and the doctor- } \\
\text { patient relationship, resulting in the } \\
\text { patient not opening up, not consenting } \\
\text { for other examinations and the Dr } \\
\text { unable to do her job effectively }\end{array}$ & $\begin{array}{l}\text { Routine nature of job/workload means } \\
\text { little things - for example, explaining } \\
\text { the examination - are forgotten/not } \\
\text { done } \\
\text { Lack of appreciation of patient dignity } \\
\text { in some situations by health care } \\
\text { professionals }\end{array}$ & $\begin{array}{l}\text { I202 } \\
\text { patients to their areas when it } \\
\text { was their turn to see a health care } \\
\text { professional }\end{array}$ & $\begin{array}{l}\text { This is common practice } \\
\text { A ticket system that uses numbers } \\
\text { rather than names is better and } \\
\text { maintains confidentiality, but this } \\
\text { requires money that the department } \\
\text { does not have }\end{array}$ \\
\hline $\begin{array}{l}\text { Shouting names of patients } \\
\text { with appointments in clinic's } \\
\text { reception }\end{array}$ & $X$ & & \begin{tabular}{l} 
The calling of names was to direct \\
\hline
\end{tabular} \\
\hline
\end{tabular}

(H) Threat: 1282 Imperfect knowledge of spoken tongue

\begin{tabular}{|c|c|c|c|c|c|}
\hline Event & Threat & Error & M\&O & LL & EC \\
\hline $\begin{array}{l}\text { Translator not available, } \\
\text { therefore a staff member had } \\
\text { to be used to give patient } \\
\text { information during the ward } \\
\text { round }\end{array}$ & $x$ & & $\begin{array}{l}\text { Staff member was used to receive and } \\
\text { give patient information about their care. } \\
\text { Unclear if translation was correct }\end{array}$ & $\begin{array}{l}\text { Translators are not prebooked by } \\
\text { junior doctors for ward rounds. } \\
\text { Over-the-phone translators are } \\
\text { either not used or not known } \\
\text { about } \\
\text { High risk of misinterpretation } \\
\text { Ad hoc NHS translators then liable? }\end{array}$ & 1282 \\
\hline $\begin{array}{l}\text { A patient was missed out during } \\
\text { ward round because no one } \\
\text { spoke the language }\end{array}$ & $x$ & & $\begin{array}{l}\text { It was decided to return when an } \\
\text { interpreter was present }\end{array}$ & & 1282 \\
\hline $\begin{array}{l}\text { [Flexi-cystoscopy] A Slovak } \\
\text { woman with no English arrived } \\
\text { for a procedure. As there was } \\
\text { no translator, the patient could } \\
\text { not be consented }\end{array}$ & & & $\begin{array}{l}\text { The patient was sent back to the waiting } \\
\text { room } \\
\text { A translator was requested } \\
\text { No one arrived } \\
\text { A translator could not be found. } \\
\text { Consequently, the clinic cancelled the } \\
\text { woman's appointment. No one told the } \\
\text { woman (who was waiting for further } \\
\text { information) }\end{array}$ & & 1282 \\
\hline
\end{tabular}

\section{(I) Threat: 130 Team dynamics}

\begin{tabular}{|l|l|l|l|l|l|}
\hline Event & Threat & Error & M\&O & LL \\
\hline $\begin{array}{l}\text { Junior doctor talking to consultant. } \\
\text { Junior doctor had not asked } \\
\text { sufficient questions to determine } \\
\text { whether a patient could be } \\
\text { discharged. Nevertheless, he told } \\
\text { the consultant that he thought } \\
\text { the patient could be discharged: "I } \\
\text { think so", opined the junior doctor }\end{array}$ & & $X$ & $\begin{array}{l}\text { Junior doctor subsequently } \\
\text { returned to the patient to ask the } \\
\text { relevant questions }\end{array}$ & $\begin{array}{l}\text { Junior doctors fear telling consultants } \\
\text { that they have missed something }\end{array}$ & $\begin{array}{l}\text { I30 } \\
\end{array}$ \\
\hline
\end{tabular}


Table 2 (Continued)

\begin{tabular}{|l|c|c|l|l|}
\hline Event & Threat & Error & M\&O & LL \\
\hline $\begin{array}{l}\text { Administrators failed to pass on a } \\
\text { message from a patient who left 2 } \\
\text { days ago explaining they could not } \\
\text { make an appointment }\end{array}$ & & $X$ & $\begin{array}{l}\text { Clinical staff were unaware of the } \\
\text { cancellation } \\
\text { Because the patient had given } \\
>24 \text { hours notice, had clinical staff } \\
\text { been aware of the cancellation, } \\
\text { they could have booked another } \\
\text { patient into the slot }\end{array}$ & $\begin{array}{l}\text { Patient-initiated cancellations are } \\
\text { often lost in the system } \\
\text { Clinical staff believe there is a divide } \\
\text { who did more. They said it was } \\
\text { unjust that administrators who did } \\
\text { more could not be rewarded }\end{array}$ \\
\hline $\begin{array}{l}\text { A consultant discovered that his } \\
\text { appointments to see patients and } \\
\text { relatives - made days earlier - had } \\
\text { been changed }\end{array}$ & $\mathrm{X}$ & & $\begin{array}{l}\text { This meant that some time slots } \\
\text { had to be rushed } \\
\text { In some cases, other parties, such } \\
\text { as family members, interpreters } \\
\text { and police officers, are left waiting }\end{array}$ & $\begin{array}{l}\text { Planning is sometimes overturned } \\
\text { Despite some patients and third } \\
\text { parties having to wait, none } \\
\text { complained }\end{array}$ \\
\hline
\end{tabular}

(J) Threat: 200 Technological in origin

\begin{tabular}{|l|l|l|l|l|l|}
\hline Event & Threat & Error & M\&O & LL & EC \\
\hline Shortage of dictaphones in clinic & & & Consultant had purchased one & Equipment shortages are the norm & 200 \\
\hline
\end{tabular}

(K) Threat: 207 Confidentiality

\begin{tabular}{|l|c|c|l|l|l|}
\hline Event & Threat & Error & M\&O & LL & EC \\
\hline $\begin{array}{l}\text { A patient handover list with identifiers } \\
\text { was left unattended by a computer and } \\
\text { another list was left on a desk }\end{array}$ & & $\mathrm{X}$ & $\begin{array}{l}\text { The lists were not moved by staff } \\
\text { Because nobody took ownership of } \\
\text { the lists, I shredded both }\end{array}$ & $\begin{array}{l}\text { Confidentiality is not considered } \\
\text { important on wards }\end{array}$ & 207 \\
\hline $\begin{array}{l}\text { A new patient was called in. The doctor } \\
\text { still had the X-ray and clinical details of } \\
\text { the previous patient on the screen }\end{array}$ & & $\mathrm{X}$ & $\begin{array}{l}\text { The doctor did not see this as a } \\
\text { problem and continued }\end{array}$ & 207 \\
\hline $\begin{array}{l}\text { A consultant with no ID visible entered } \\
\text { the ward and began reading patient notes }\end{array}$ & $\mathrm{X}$ & $\begin{array}{l}\text { The consultant was challenged by a nurse } \\
\text { The consultant apologized for not } \\
\text { making his ID visible }\end{array}$ & 207 \\
\hline
\end{tabular}

(L) Threat: 30I Layout design

\begin{tabular}{|l|c|c|l|l|l|}
\hline Event & Threat & Error & M\&O & LL & EC \\
\hline $\begin{array}{l}\text { Long queue to check in to fracture clinic } \\
\text { delays care and obstructs those with broken } \\
\text { limbs, who need more space, for example, } \\
\text { persons on crutches }\end{array}$ & $X$ & & $\begin{array}{l}\text { Previously, patients and relatives } \\
\text { have had to sit on the floor }\end{array}$ & $\begin{array}{l}\text { Overbooking exacerbates the } \\
\text { overcrowding problem } \\
\text { The clinic's waiting area is too } \\
\text { small }\end{array}$ & \begin{tabular}{l}
30 I \\
\hline $\begin{array}{l}\text { Cables and cords lying all over the floor of } \\
\text { the theater }\end{array}$
\end{tabular} \\
$\begin{array}{l}\text { Possible to trip and disrupt surgery, for } \\
\text { example, by desterilizing surgery or an open } \\
\text { area, creating an infection risk }\end{array}$ & $X$ & & Staff stepped around the cables & $\begin{array}{l}\text { Floor sockets could reduce the } \\
\text { trip/infection hazard }\end{array}$ & $30 I$ \\
\hline
\end{tabular}

(M) Threat: 302 Air conditioning

\begin{tabular}{|l|c|c|l|l|l|}
\hline Event & Threat & Error & M\&O & LL & EC \\
\hline $\begin{array}{l}\text { No air-con in the windowless } \\
\text { room where the manipulation } \\
\text { was taking place, so the door } \\
\text { was left open }\end{array}$ & $\mathrm{X}$ & & $\begin{array}{l}\text { The only time the door was } \\
\text { closed was when an X-ray was } \\
\text { being done }\end{array}$ & $\begin{array}{l}\text { Poorly designed rooms lead to failures in } \\
\text { maintaining confidentiality. [Was the room fit for } \\
\text { purpose? This case demonstrates how systems } \\
\text { theory can help explain rule violations - in this } \\
\text { case, the doctor's failure to maintain patient } \\
\text { confidentiality] }\end{array}$ \\
\hline
\end{tabular}


Table 2 (Continued)

\begin{tabular}{|l|c|c|l|l|l|}
\hline Event & Threat & Error & M\&O & LL & EC \\
\hline $\begin{array}{l}\text { [Vascular ward round] No air } \\
\text { conditioning }\end{array}$ & $X$ & & $\begin{array}{l}\text { Doctors were sweating profusely, } \\
\text { as was I. Patients were obviously } \\
\text { uncomfortable and had to drink } \\
\text { more }\end{array}$ & $\begin{array}{l}\text { Potential for dehydration and infection spread, } \\
\text { leading to longer stays in hospital and higher } \\
\text { rates of morbidity and mortality }\end{array}$ & 302 \\
\hline
\end{tabular}

(N) Threat: 1000 Equipment

\begin{tabular}{|l|c|c|c|l|l|}
\hline Event & Threat & Error & M\&O & LL & EC \\
\hline $\begin{array}{l}\text { [Trauma theater] Only one K-wire set left. } \\
\text { It was used in the procedure }\end{array}$ & $X$ & & & $\begin{array}{l}\text { System unable to ensure adequate surgical supplies } \\
\text { Surgery may have been delayed if second K-wire set was } \\
\text { required }\end{array}$ & \begin{tabular}{l}
1000 \\
\hline
\end{tabular} \\
\hline
\end{tabular}

(O) Threat: 130 I Guidelines not followed

\begin{tabular}{|c|c|c|c|c|c|}
\hline Event & Threat & Error & M\&O & LL & EC \\
\hline $\begin{array}{l}\text { A patient was brought into theater, then } \\
\text { exposed from the waist down. The theater } \\
\text { doors were left open. Passing staff could see } \\
\text { the patient }\end{array}$ & $x$ & $x$ & $\begin{array}{l}\text { Staff entered and exited } \\
\text { through the doors, but no } \\
\text { one closed them } \\
\text { They were only closed } \\
\text { when the next patient } \\
\text { (under local anesthetic) } \\
\text { was brought into theater }\end{array}$ & $\begin{array}{l}\text { At times, the dignity of the patient was } \\
\text { compromised } \\
\text { It appeared that in the case of patients } \\
\text { under general anesthetic, the doors } \\
\text { were left open } \\
\text { In the case of patients under local } \\
\text { anesthetic, the doors were closed } \\
\text { Staff might have left the doors open } \\
\text { because of the heat. Their response } \\
\text { to an environmental threat [heat] } \\
\text { compromised patient dignity }\end{array}$ & 1301 \\
\hline $\begin{array}{l}\text { [Theater] Theater commenced without the } \\
\text { team briefing being completed } \\
\text { This could have led to confusion over } \\
\text { theater patients' care plans }\end{array}$ & $x$ & $X$ & $\begin{array}{l}\text { It seemed the plan was } \\
\text { communicated only } \\
\text { when the World Health } \\
\text { Organization checklist had } \\
\text { been completed }\end{array}$ & $\begin{array}{l}\text { When questioned, staff were unsure } \\
\text { why the team briefing had not been } \\
\text { completed } \\
\text { It seemed that practices had emerged } \\
\text { to deal with situations where briefings } \\
\text { had not been completed [systems } \\
\text { theory } \\
\text { partial/1,40,4l sugsent team briefings] }\end{array}$ & 1301 \\
\hline $\begin{array}{l}\text { Two intensive care unit (ICU) patients } \\
\text { were judged ready to be moved to a ward. } \\
\text { There were no beds available. A bed } \\
\text { became available out-of-hours. Contrary } \\
\text { to guidelines, one of the patients was } \\
\text { transferred out of the ICU in the middle } \\
\text { of the night, resulting in an elevated level } \\
\text { of risk to the patient. In this case, it also } \\
\text { caused the doctor and the patient's family a } \\
\text { degree of confusion and inconvenience }\end{array}$ & $x$ & $x$ & $\begin{array}{l}\text { Staff claimed they had } \\
\text { raised the issue of bed } \\
\text { shortages with managers }\end{array}$ & $\begin{array}{l}\text { Only hospital managements can resolve } \\
\text { resourcing issues } \\
\text { Staff should follow guidelines }\end{array}$ & $\begin{array}{l}130 \mid \\
\text { and } \\
300\end{array}$ \\
\hline
\end{tabular}

Abbreviations: FI, Charge Nurse; PPE, personal protective equipment; NHS, (UK) National Health Service; HCA, Health care assistant.

ment of an electronic TEAM-W (that, as discussed, could have been stored on a portable electronic device such as an iPad). The use of a hard-copy TEAM-W significantly complicated data analysis (including cross-checking). The large volume of data collected from multiple sites and scenarios meant it was impossible to cross-check within the time available. There were no funds allocated for the post-trial creation of an electronic database. Monies are being sought for a second field trial, supported by an iPad-hosted TEAM-W developed in consultation with the School of Medicine and NHS.

\section{Data}

The student observers (henceforth referred to as observers) generated a large volume of data. Subjected to quantitative 
(frequency) and qualitative (case study) analysis, the data showed health care to be a threat-rich environment with errors (some consequential) a commonplace.

\section{Quantitative analysis}

Where no suitable subcode could be found, the observers scored against the main code. For example, regarding threats that were judged human in origin, 5 were scored against " 100 Human in origin". Regarding threats that were judged technological in origin, 20 were scored against " 200 Technological in origin" (Table 1).

\section{Analysis}

\section{Pedagogic impact}

The School of Medicine summarized student feedback in a pie chart (Figure 2). Although operationalizing NOSA as an educational tool in live settings was not unproblematic (refer observers' comments in Box S1), observers' feedback on the educational benefits of the SSC was overwhelmingly positive. Regarding "new skills gained", typical Competence Log Book comments were:

- improved observational skills. One observer wrote: "I have developed my skills in observing a scenario from more of an objective view, whereas previously I watched just to gain clinical knowledge"

- improved listening skills;

- improved communication skills. One observer wrote: "I had to explain the project and make sure people did not feel threatened by us";

- ability to empathize;

- better at maintaining situational awareness;

- ability to critique medical practice;

- tenacity (desire to "get to the bottom of things");

- better at uncovering the truth of a situation;

- better at record-keeping;

- better at putting staff at their ease;

- methodical skepticism;

- objectivity;

- ability to "stand apart" (disinterestedness);

- capacity for reflection;

- diplomacy;

- confidence. One observer wrote: "[I have learned] how to question NHS staff [...] about the system [...] without fearing intimidation, or being criticised for [asking questions]";

- restraint (the importance for safety of not blaming).

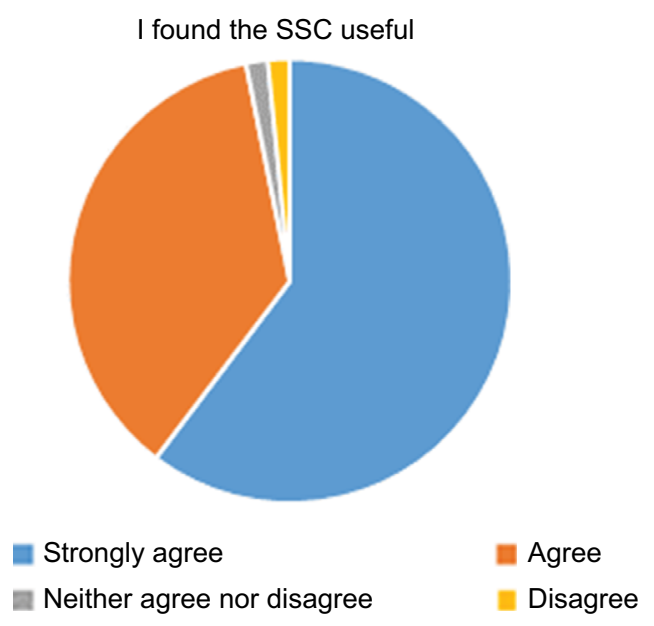

Figure 2 Student feedback pie chart.

Abbreviation: SSC, student selected component.

\section{Insights into the human factors aspects of health care provision}

The following claims should be considered against the potential biases described in the "Reflections on the methodology" section:

1. The elements of health care provision observed during the study presented a threat-rich environment.

2. Errors, some consequential, were made by medical professionals.

3. Systems theory posits that the origins of error are complex. Frequently, they are the product of individual and organizational failings: "[H]uman mistakes $[\ldots]$ rarely have a single underlying contributory factor. Error is the product of design, procedures, training and/or the environment". ${ }^{20}$ This study confirms the systems theory view of error: some errors resulted from willful neglect. For example, the persistent failure to gel (sterilize) hands. One observer wrote, "[C]onsultant washed hands total of 5 times for approx 30 patients - juniors didn't wash hands at all"; "Hands not gelled by doctors throughout the ward round"; "HCA touched bin and then touched patient without washing hands [...] HCA did not sanitize hands during time on ward and touched 3 further patients".

Others, such as the guideline-flouting night-time transfer from ICU of a patient, were induced by circumstance (a bed shortage).

4. Regarding basic safety procedures such as hand sterilization, there appeared to be a subculture among consultants and doctors of ignoring advice (e.g., signage reminding staff to gel). Referencing Hatch's ${ }^{42}$ work, Bennett and 
Stewart ${ }^{43}$ observed: "Organizational culture is seldom monolithic. Organizations often consist of numerous subcultures, constituted in part through workers' shared interests, beliefs, skills and profession". Subcultures produce "inconsistencies". ${ }^{44}$ Several questions occur. For example:

- Why did some consultants and doctors ignore hygiene guidelines?

- To what degree does consultants' behavior influence doctors' behavior (e.g., in regard to hygiene)? Armstrong ${ }^{44}$ noted how an organization's culture is shaped by senior management. Consultants' behavior could be normative. Janis ${ }^{45}$ notes a proclivity for "concurrence-seeking behavior" in tight-knit groups. He claims the members of such groups are subject to "conformity pressures" and that group behavior may exhibit "derangement".

- Is it reasonable to conclude that health care fosters subcultures that harbor deviant behaviors?

\section{NHS England ${ }^{46}$ defines never-events as}

[S]erious incidents that are wholly preventable [...]. Each Never Event [...] has the potential to cause serious patient harm or death. However, serious harm or death is not required to have happened [...] for [an] incident to be categorized as a Never Event.

Observers recorded five never events (code 1201). As the nomenclature implies, a never event has the potential to harm or kill. Never events include:

- wrong-site surgery;

- retained foreign object postprocedure;

- wrong-route administration of medication;

- $\quad$ scalding of patients. ${ }^{47}$

The data should be considered against a background of public concern about patient safety.

\section{Conclusion}

Regarding the project's first objective (see Introduction section), the safety benefits of conducting a NOSA in health care include:

- identification of bad and good practice;

- reasons for work-arounds (expedients);

- through the production of thick description, documenting the lived reality of medical labor;

- provision of information in support of informed policymaking by the government and trusts.
Regarding the project's second objective, under the mentorship of the Convenor and clinicians (Table S1), the fifth-year students completed a large number of TEAM-Ws to a high standard. The forthright nature of the comments evidenced a lack of inhibition (suggesting confidence in the methodology and a desire to contribute). The Convenor's promise that data would be anonymized helped secure observers' and observees' commitment. Anonymous reporting within a just culture encourages flight crew commitment to NOSA. ${ }^{23}$ Regarding the project's third objective, a School of Medicine survey confirmed the project's educational benefits.

Of course, the above claims should be considered against the possible research biases discussed in the "Reflections on the methodology" section. To reprise one potential source of bias, it is always possible that observees "performed" for the observers. Given the difficulty of quantifying the Hawthorne effect, data, inferences and conclusions should be tested. It is also possible that observers cloaked failings by indulging their own research interests (e.g., by focusing on a narrow range of clinical care issues). As with knowledge generated in the natural sciences, knowledge generated in the social sciences is potentially refutable.

The results of the study suggest three policy developments.

First, the UK General Medical Council should mandate that all medical students perform a NOSA in fulfillment of their degree. As discussed, the 11 students claimed to have benefited in various ways from their participation in the trial. Three said they would like to be involved in further patient safety research.

Second, participating NHS Trusts should be encouraged to act on students' NOSA findings. NOSA-derived insights should be considered a useful supplement to insights derived from established patient safety systems (such as in-house confidential error reporting systems).

Third, in light of the continuing high level of avoidable deaths in NHS hospitals, the UK Department of Health should adopt NOSA as a cornerstone risk assessment and management tool. It is hypothesized that, other things being equal, groups are capable of producing superior analyses than individuals working alone. Shaw ${ }^{48}$ observes:

This effect can be accounted for by the increased number of judgments in the group [...] the wider range of knowledge in the group $[\ldots]$ and the influence of the more confident (and more accurate) individuals in the group [...].

The NOSA tool should be used by mixed teams. NOSA teams should possess a range of expertise and experience. 
A team might consist of a radiologist, junior doctor, nurse, paramedic and pharmacist.

NOSAs should be notified to all staff in good time, comprehensively planned and adequately resourced. NHS Trusts must ensure that funds are available to implement suggested remediations. Failure to implement remediations will undermine confidence in NOSA, reduce safety audit buy-in and, possibly, undermine staff commitment to the organization's goals. Trust is a fragile resource. Taking a long time to build, it can be destroyed in an instant. ${ }^{49}$

\section{Acknowledgments}

The Convenor would like to thank the senior academics and clinicians who funded and supported this trial. Special thanks go to the senior clinician who helped develop the TEAM-W coding system and to the 11 fifth-year medical students who trialed TEAM-W. These talented and dedicated young people are a credit to their university and the NHS.

\section{Disclosure}

The author reports no conflicts of interest in this work.

\section{References}

1. Institute of Medicine. To Err is Human: Building a Safer Health System. Washington DC: National Academy Press; 2000.

2. Department of Health. An Organization with a Memory. London: The Stationery Office; 2000.

3. National Patient Safety Agency. Seven Steps to Patient Safety. London: The National Patient Safety Agency; 2004.

4. Waterson P, Catchpole K. Human factors in healthcare: welcome progress, but still scratching the surface. BMJ Qul Saf. 2016;25(7):480-484.

5. Stittle J. In critical condition. icsa The Governance Institute. Available from: https://www.icsa.org.uk/knowledge/governance-and-compliance/ analysis/news-analysis-in-critical-condition. Accessed October 1, 2016.

6. Bennett SA. Disasters and mishaps: the merits of taking a global view. In: Masys A, editor. Disaster Forensics: Understanding Root Cause and Complex Causality. Cham: Springer; 2016:151-174.

7. Moshansky VP. Moshansky, Commission of Inquiry into the Air Ontario Accident at Dryden, Ontario: Final Report (Volumes 1-4). Ottawa: Minister of Supply and Services; 1992.

8. Haddon-Cave C. The Nimrod Review. An Independent Review into the Broader Issues Surrounding the Loss of the RAF Nimrod MR2 Aircraft XV230 in Afghanistan in 2006. HC 1025. London: Her Majesty's Stationery Office; 2009.

9. Weir DTH. Risk and disaster: the role of communications breakdown in plane crashes and business failure. In: Hood C, Jones DKC, editors. Accident and Design. London: UCL Press; 1996:114-126.

10. Snook S. Friendly Fire: The Accidental Shootdown of U.S. Black Hawks over Northern Iraq. New Jersey, NJ: Princeton University Press; 2000.

11. Hollnagel E. Barriers and Accident Prevention. Aldershot: Ashgate Publishing Ltd; 2004.

12. Dekker S. Resilience engineering: chronicling the emergence of confused consensus. In: Hollnagel E, Woods DD, Leveson N, editors. Resilience Engineering: Concepts and Precepts. Aldershot: Ashgate Publishing Ltd; 2006:77-92.

13. Reason J. A Life in Error. Aldershot: Ashgate Publishing Ltd; 2013.

14. Shorrock S, Leonhardt J, Licu T, Peters C. Systems Thinking for Safety: Ten Principles. Brussels: Eurocontrol; 2014.
15. Lagadec P. Ounce of prevention worth a pound in cure. Management Consultancy; 1993.

16. Perrow C. Normal Accidents. New York, NY: Basic Books; 1984.

17. Brookes A. Flights to Disaster. Shepperton: Ian Allan; 1996.

18. Weick KE. The vulnerable system: An analysis of the Tenerife Air Disaster. J Manage. 1990;16(3):571-593.

19. Bennett SA. Human factors for maintenance engineers and others - a prerequisite for success. In: Blockley R, Shyy W, editors. Encyclopedia of Aerospace Engineering. Chichester: Wiley; 2010: 4703-4710.

20. Harris D. Improving aircraft safety. The Psychologist. 2014;27(2): 90-94.

21. Latour B. Reassembling the Social: An Introduction to Actor-Network Theory. Oxford: Oxford University Press; 2005.

22. Woods DD, Dekker S, Cook R, Johannsen L, Sarter N. Behind Human Error. Aldershot: Ashgate Publishing Ltd; 2010.

23. Eurocontrol. Normal Operations Safety Survey (NOSS) [webpage on the Internet]. Available from: http://www.eurocontrol.int/articles/ normaloperationssafetysurveynoss. Accessed October 15, 2016.

24. International Civil Aviation Organization. Line Operations Safety Audit. Montreal: International Civil Aviation Organization; 2002.

25. Hollnagel E. Safety-I and Safety-II. The Past and Future of Safety Management. Aldershot: Ashgate Publishing Ltd; 2014.

26. Kolb D. Experiential Learning: Experience as the Source of Learning and Development. Englewood Cliffs, NJ: Prentice Hall; 1984.

27. Revans R. Action Learning: New Techniques for Management. London: Blond \& Briggs Ltd; 1980.

28. Leonard HS, Marquardt MJ. The evidence for the effectiveness of action learning. Action Learning: Res Pract. 2010;7(2):121-136.

29. Denscombe M. The Good Research Guide: For Smallscale Social Research Projects. London: McGrawHill Education; 2014.

30. Lewin K. Action research and minority problems. J Soc. 1946;2(4): $34-46$.

31. International Civil Aviation Organisation. Line Operations Safety Audit. Montreal: International Civil Aviation Organisation; 2002.

32. Schön D. The Reflective Practitioner, How Professionals Think in Action. New York, NY: Basic Books; 1983.

33. Taylor P, Richardson J, Yeo A, Marsh I, Trobe K, Pilkington A. Sociology in Focus. Ormskirk: Causeway Press; 1995.

34. Gordon S, Mendenhall P, O'Connor BB. Beyond the Checklist. What else Healthcare can Learn from Aviation Teamwork and Safety. Ithaca: ILR Press; 2013.

35. Gilbert N Stoneman P. Researching Social Life. 4th ed. London: Sage; 2016.

36. Triggle N. Junior doctors' strike: all-out stoppage 'a bleak day'. Available from: http://www.bbc.com/news/health-36134103. Accessed October 10, 2016.

37. Sculthorpe, $T$ and Pickles, K Jeremy Hunt pleads with junior doctors to cancel the strike. The Daily Mail. 2016. http://www.dailymail.co.uk/ news/article-3440125. Accessed July 1, 2017.

38. Allsop P, Overton S, Stewart N, Stewart P. Recognizing Risk and Improving Patient Safety - Mildred's Story. Leicester: University of Leicester Audio Visual Services; 2010.

39. Dunhill L. Trusts heading for $£ 670$ million deficit, says Regulator. NHS, Health Services Journal. 2016. Available from https://www. hsj.co.uk/topics/finance-and-efficiency/trusts-heading-for-670m-endof-year-deficit-says-regulator/7013453 article?blocktitle=News(grid)\&contentID=20682. Accessed July 14, 2017.

40. Vaughan D. The Challenger Launch Decision. Risky Technology, Culture and Deviance at NASA. Chicago: University of Chicago Press; 1997.

41. Rasmussen J. Risk management in a dynamic society: a modeling problem. Safety Sci. 1997;27(2-3):183-213.

42. Hatch MJ. Organization Theory: Modern, Symbolic and Postmodern Perspectives. Oxford: Oxford University Press; 1997.

43. Bennett SA, Stewart N. Employees' experience of, and attitudes towards team working at a National Health Service (NHS) District General Hospital. Int J Risk Manag. 2007;9(3):145-166. 
44. Armstrong M. A Handbook of Personnel Management Practice. London: Kogan Page; 1996.

45. Janis IL. Victims of Groupthink. Boston: Houghton Mifflin Company; 1972.

46. NHS England. Revised Never Events Policy and Framework. 2015. Available from https://improvement.nhs.uk/uploads/documents/neverevnts-pol-framwrk.pdf. Accessed July 14, 2017.
47. NHS England. Never Events List 2015/16. 2015. Available from https://www.england.nhs.uk/wp-content/uploads/2015/03/never-evntslist-15-16.pdf. Accessed July 14, 2017.

48. Shaw ME. Group Dynamics. The Psychology of Small Group Behavior. New York, NY: McGraw-Hill Book Company; 1971.

49. Lerangis P. The Sword Thief. New York, NY: Scholastic Corporation; 2009. 


\section{Supplementary materials}

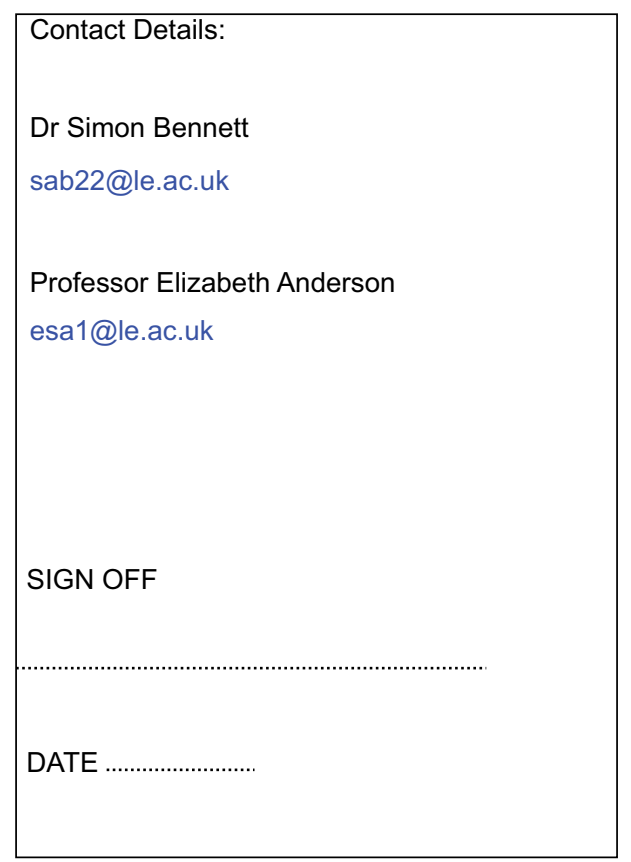

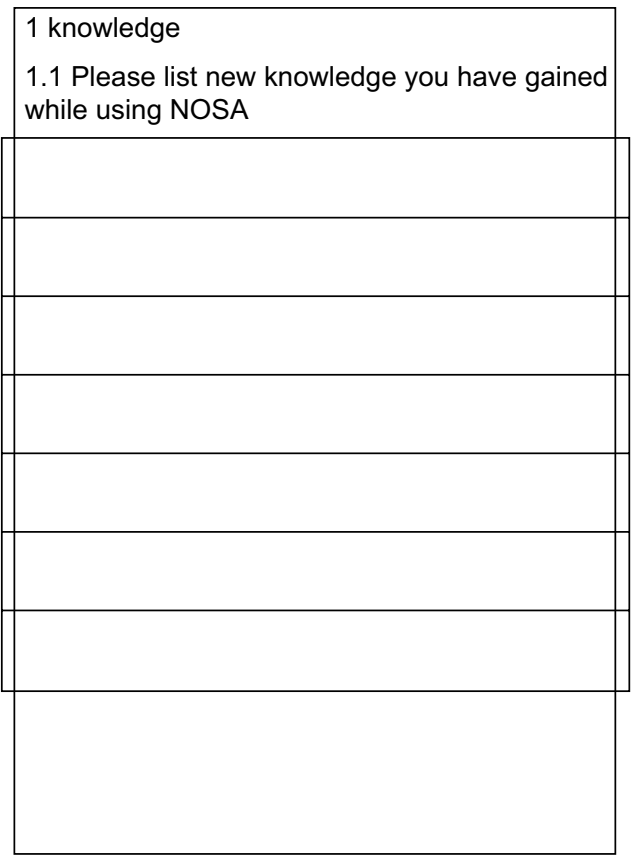

Competence Log Book

This booklet is designed to demonstrate an ability apply the aviation-derived Normal Operation Safety Audit (NOSA) methodology in a variety of health care settings

NAME

12 Specifically, how was this new knowledge gain

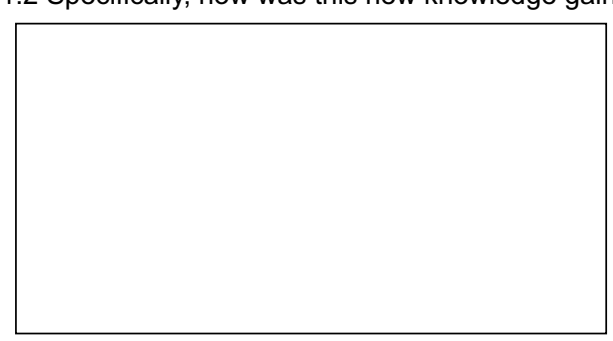

1.3 Other elements of your learning you wish to record, particularly what you have gained from your practice and experimental learning

Figure SI Competence Log Book. 
Table SI Student roster

Wednesday 3 Ist August

\begin{tabular}{llllll}
\hline Attend & $0800 \mathrm{~h}$ & $\begin{array}{l}0755 \mathrm{~h} \text { Junior doctor handover and } \\
\text { emergency Urology ward round }\end{array}$ & $\begin{array}{l}\text { II } 100 \mathrm{~h} \text { onward: } \\
\text { Urology ward }\end{array}$ & $\begin{array}{l}0845 \mathrm{~h} \text { Mental } \\
\text { health clinic }\end{array}$ & $0800 \mathrm{~h}$ Fracture clinic \\
$\begin{array}{l}\text { Observer team } \\
\text { (OT) }\end{array}$ & $\mathrm{D}$ & $\mathrm{C}$ & $\mathrm{E}$ & $\mathrm{A}$ & $\mathrm{B}$ \\
\hline
\end{tabular}

Thursday Ist September

\begin{tabular}{|c|c|c|c|c|c|}
\hline \multirow[t]{3}{*}{ 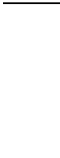 } & $0755 \mathrm{~h}$ Theater & I $300 \mathrm{~h}$ Theater & 08:30 h Day Case & I230-I300 h Meet up with Urology consultant & $0800 \mathrm{~h}$ Fracture clinic \\
\hline & & & Theaters & |330-|445 h Local Urology MDT & \\
\hline & & & & $\begin{array}{l}\text { I } 500 \text { h onward: Urology triage - On-call junior } \\
\text { doctors }\end{array}$ & \\
\hline OT & $\mathrm{E}$ & $\mathrm{D}$ & B & $\cos ^{2} \cos \cos \mathrm{cos}$ & $A$ \\
\hline
\end{tabular}

Monday 5th September

\begin{tabular}{|c|c|c|c|c|c|c|}
\hline & $\begin{array}{l}0755 \text { h Students' } \\
\text { theater }\end{array}$ & $\begin{array}{l}\text { I } 300 \text { h Students' } \\
\text { theater }\end{array}$ & $\begin{array}{l}0830 \mathrm{~h} \text { Main } \\
\text { theaters }\end{array}$ & $\begin{array}{l}\text { I } 300 \text { h Flexible cystoscopy } \\
\text { list, Urology }\end{array}$ & $\begin{array}{l}0845 \text { h Mental } \\
\text { health clinic }\end{array}$ & $0800 \mathrm{~h}$ Trauma theater \\
\hline OT & $\mathrm{E}$ & C & A & A & B & D \\
\hline
\end{tabular}

Tuesday 6th September

\begin{tabular}{|c|c|c|c|c|c|}
\hline OT & $\begin{array}{l}0900 \mathrm{~h} \text { Ward with } \\
\text { FYI doctors }\end{array}$ & $\begin{array}{l}0755 \mathrm{~h} \text { Junior doctor handover and } \\
\text { emergency Urology ward round }\end{array}$ & $\begin{array}{l}\text { I } 330 \text { h Urology } \\
\text { outpatients }\end{array}$ & $\begin{array}{l}0845 \text { h Mental health } \\
\text { clinic }\end{array}$ & $\begin{array}{l}0800 \mathrm{~h} \text { Trauma } \\
\text { theater } \\
\mathrm{B}\end{array}$ \\
\hline
\end{tabular}

Wednesday 7 th September

\begin{tabular}{|c|c|c|c|c|c|c|}
\hline & $\begin{array}{l}0800 \mathrm{~h} \text { Ward with } \\
\text { Matron and HCA }\end{array}$ & $\begin{array}{l}\text { I300 h } \\
\text { Outpatients }\end{array}$ & $\begin{array}{l}0845 \mathrm{~h} \\
\text { Lithotripsy } \\
\text { (ESWL) list }\end{array}$ & $\begin{array}{l}\text { I } 300 \text { h Urology ward, } \\
\text { junior doctors }\end{array}$ & $\begin{array}{l}0845 \text { h Mental } \\
\text { health clinic }\end{array}$ & 0800 h Fracture clinic \\
\hline OT & E & C & B & A & D & C \\
\hline
\end{tabular}

Thursday 8th September

\begin{tabular}{llll}
\hline $\begin{array}{l}\text { round } \\
\text { ron hard }\end{array}$ & $\begin{array}{l}\text { I300 h Matron/ } \\
\text { HCA on ward in the } \\
\text { afternoon }\end{array}$ & $\begin{array}{l}0845 \mathrm{~h} \text { TRUS } \\
\text { biopsy of prostate } \\
\text { list, Urology }\end{array}$ & $\begin{array}{l}0800 \mathrm{~h} \text { Fracture } \\
\text { clinic }\end{array}$ \\
OT $\quad$ B & C & E & D \\
\hline
\end{tabular}

Note: The students were divided into 5 groups: A, B, C, D, E.

Abbreviations: HCA, Health-care assistant; ESWL, Extracorporeal shock-wave lithotripsy; MDT, Multi-disciplinary team; TRUS, trans-rectal ultrasound.

Table S2 Convenor-generated observational data

Afternoon urology clinic in a large city hospital.

\begin{tabular}{|c|c|c|c|c|c|c|c|c|c|}
\hline Consulting room & In & Out & Minutes & In & Out & Minutes & In & Out & Minutes \\
\hline 6 & I347 h & $1410 \mathrm{~h}$ & 23 & $1419 \mathrm{~h}$ & $1439 \mathrm{~h}$ & 10 & I $448 \mathrm{~h}$ & $1512 \mathrm{~h}$ & 24 \\
\hline 8 & $1408 \mathrm{~h}$ & $1415 \mathrm{~h}$ & 7 & $1422 \mathrm{~h}$ & $1426 \mathrm{~h}$ & 4 & $1436 \mathrm{~h}$ & $\mathrm{l} 442 \mathrm{~h}$ & 6 \\
\hline 9 & $1416 \mathrm{~h}$ & $1425 \mathrm{~h}$ & 9 & $1428 \mathrm{~h}$ & $1438 \mathrm{~h}$ & 10 & $\mathrm{l} 440 \mathrm{~h}$ & $1455 \mathrm{~h}$ & 15 \\
\hline
\end{tabular}

Note: No scheduled breaks for staff (although some were able to take an informal break). Timings for early part of clinic. 


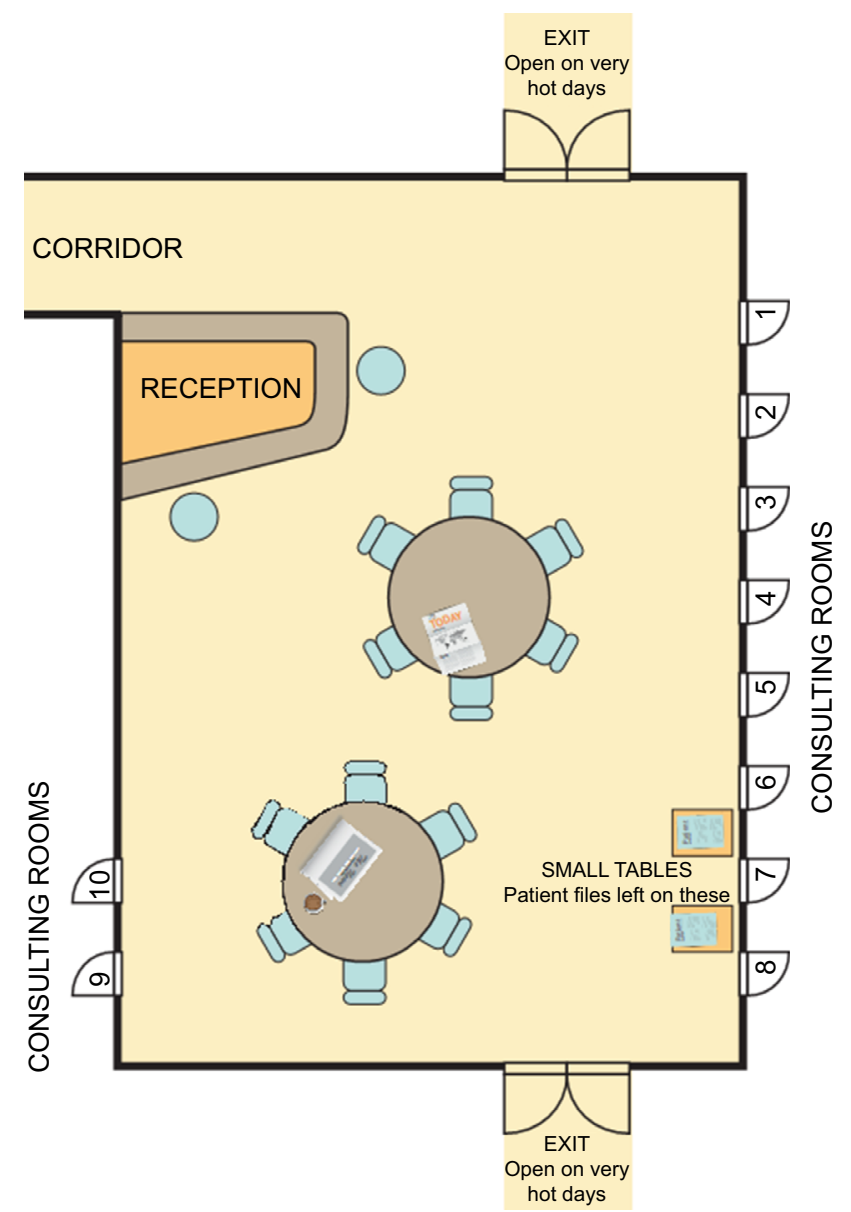

- Afternoon clinic

- Rooms 6, 8, 9 in use

- Very hot day

- Exits open - ventilation

- Grounds open to public

- People wander through clinic

- Patient files left on tables outside rooms

- Practice a threat to patient confidentiality?

Figure S2 The clinic's layout.

\section{Box S I}

During their end-of-SSC presentations, the observers made the following comments:

- Observers must be knowledgeable.

- It is tempting for observees to "teach" observers.

- It is tempting for observees to use observers as a resource (e.g., asking them to fetch patient files).

- Compounding the problem of enrollment, observers felt obligated to help when colleagues seemed under pressure (e.g., by closing the curtains around beds to maintain patient dignity).

- It can be difficult to sustain disinterestedness.

- The "filter-down" approach to informing staff of a NOSA is too haphazard. All staff likely to be observed should be informed individually.

- There is a risk that observers could distract clinical staff. "In extremis", errors could be induced.

- Medical scenarios are often actor and action-rich. Sometimes there were so many observees that it was difficult to maintain situation awareness. The faster the observees worked, the more difficult it was to record actions, interactions, outcomes and personnel changes.

- Because machines must be operated "as directed", machine-centric work is easier to interpret than patient-centric work (where there may be $\mathrm{n}$ ways of achieving a goal/n solutions to a problem).

- The fact that some consultants have their own "modus operandi" adds to the problem of keeping an accurate record.

- The observers received positive feedback from clinicians, mainly because the observers were trying to understand the circumstances behind human error.

- The coding system needs development.

- A NOSA helps staff appreciate that a health care system is a network of interdependent actants.

- Work-arounds recorded by observers should be propagated.

- From a patient safety standpoint, the observers felt that this type of holistic, system-focused audit is more useful than a Care Quality Commission audit. 


\section{Publish your work in this journal}

Risk Management and Healthcare Policy is an international, peer-reviewed open access journal focusing on all aspects of public health, policy, and preventative measures to promote good health and improve morbidity and mortality in the population. The journal welcomes submitted papers covering original research, basic science, clinical and epidemiological

Submit your manuscript here: https://www.dovepress.com/risk-management-and-healthcare-policy-journal

studies, reviews and evaluations, guidelines, expert opinion and commentary, case reports and extended reports. The manuscript management system is completely online and includes a very quick and fair peerreview system, which is all easy to use. Visit http://www.dovepress.com/ testimonials.php to read real quotes from published authors. 